\title{
PERAMALAN INFLASI MENGGUNAKAN METODE SARIMA DAN SINGLE EXPONENTIAL SMOOTHING (STUDI KASUS: KOTA BANDUNG)
}

\author{
Rifqi Fahrudin, Irfan Dwiguna Sumitra \\ Universitas Komputer Indonesia \\ E-mail: rifqifhrdn@gmail.com
}

\begin{abstract}
Inflation is one of the economic phenomena that is always interesting to discuss mainly related to its broad impact on macroeconomics, such as economic growth, external balance, competitiveness, interest rates, and even income distribution. Inflation plays an important role in determining economic conditions, so it needs to get serious attention from various circles, especially the monetary authority responsible for controlling inflation. If inflation can be predicted with high accuracy, it can certainly be used as a basis for government policy making in anticipating future economic activity. This study aims to produce inflation forecast data. The method used in this study is the SARIMA method and Single Exponential Smoothing. In forecasting the rate of inflation where data is in the form of time series, the SARIMA method can show more accurate forecasting results than using the SES method. Based on the comparison of the overall forecasting model, the SARIMA model $(2,1,1)(1,1,1) 11$ has the smallest error value with a MAD value of 0.117, MSE 0.023 and $0.72 \%$ for MAPE. From these results it was collected that the inflation forecasting in Bandung using the SARIMA method has a high accuracy value.
\end{abstract}

Key words: Inflation, Forecasting, SARIMA, SES

\begin{abstract}
ABSTRAK
Inflasi merupakan salah satu fenomena ekonomi yang selalu menarik dibahas terutama berkaitan dengan dampaknya yang luas terhadap ekonomi makro, seperti pertumbuhan ekonomi, keseimbangan eksternal, daya saing, tingkat bunga, bahkan distribusi pendapatan. Inflasi berperan penting dalam menentukan kondisi perekonomian, sehingga perlu mendapatkan perhatian serius dari berbagai kalangan khususnya otoritas moneter yang bertanggung jawab mengendalikan inflasi. Jika inflasi dapat diramalkan dengan akurasi yang tinggi, tentunya dapat dijadikan dasar pengambilan kebijakan pemerintah dalam mengantisipasi aktivitas ekonomi di masa depan. Penelitian ini bertujuan untuk menghasilkan ramalan data inflasi. Metode yang digunakan dalam penelitian ini adalah metode SARIMA dan Single Exponential Smoothing. Dalam peramalan laju nilai inflasi dimana data berupa time series, metode SARIMA dapat menunjukan hasil peramalan yang lebih akurat dibandingkan dengan menggunakan metode SES. Bedasarkan perbandingan model peramalan secara keseluruhan, model SARIMA $(2,1,1)(1,1,1){ }^{11}$ memiliki nilai error terkecil dengan nilai MAD 0,117, MSE 0,023 dan 0,72\% untuk MAPE. Dari hasil tersebut disumpulkan bahawa peramalan inflasi Kota Bandung menggunakan metode SARIMA memiliki nilai akurasi yang tinggi.
\end{abstract}

Kata Kunci: Inflasi, Peramalan, SARIMA, SES 


\section{PENDAHULUAN}

Inflasi merupakan salah satu fenomena ekonomi yang selalu menarik dibahas terutama berkaitan dengan dampaknya yang luas terhadap ekonomi makro, seperti pertumbuhan ekonomi, keseimbangan eksternal, daya saing, tingkat bunga, bahkan distribusi pendapatan. Banyak kajian yang membahas inflasi, tidak hanya cakupan regional, nasional, namun juga internasional. Inflasi cenderung terjadi pada negara-negara berkembang seperti halnya Indonesia yang merupakan negara agraris. Krisis ekonomi yang dipicu oleh gejolak nilai tukar rupiah telah berdampak sangat luas pada seluruh sendi perekonomian dan tatanan kehidupan. Krisis ekonomi yang telah terjadi, paling tidak dalam konteks ini, memberikan pelajaran yang berharga akan pentingnya penciptaan kestabilan moneter (kestabilan nilai rupiah) sebagai prasyarat bagi kelangsungan pembangunan ekonomi yang berkelanjutan.

Peramalan adalah metode untuk memperkirakan suatu nilai di masa depan dengan menggunakan data masa lalu. Data inflasi merupakan salah satu data runtun waktu, dengan memodelkan data waktu lampau dapat digunakan untuk meramalkan data waktu mendatang. Dalam peramalan laju nilai inflasi dimana data berupa runtun waktu, metode Seasonal Autoregressive Integrated Moving Average atau lebih dikenal dengan metode SARIMA dapat menunjukan hasil peramalan yang mampu mengikuti pergerakan data aktual dari laju nilai inflasi. Sedangkan untuk metode Single Exponential Smoothing memiliki nilai akurasi yang baik pada data yang memiliki fluktuasi di sekitar rata-rata.

Penelitian ini akan menggunakan metode SARIMA dan SES dengan melihat adanya pola musiman sebagai usaha untuk menghasilkan peramalan yang lebih akurat dan mendekati nilai aktual. Hasil tersebut dapat dijadikan acuan untuk pemerintah dalam pengambilan kebijakan, dapat juga digunakan sebagai bahan pertimbangan bagi pelaku bisnis terutama pelaku usaha bisnis ekspor dan impor.

\section{METODOLOGI PENELITIAN}

1. Inflasi

Inflasi adalah suatu keadaan yang mengakibatkan naiknya harga secara umum atau proses meningkatnya harga-harga secara umum dan terus menerus (berkesinambungan) [1]. Inflasi dengan kata lain merupakan proses menurunnya nilai mata uang secara kontinu. Inflasi merupakan proses suatu kejadian dan bukan tinggi rendahnya tingkat harga. Sehingga, jangan menganggap kalau tingkat harga tinggi itu berarti inflasi tinggi. Inflasi terjadi kalau proses kenaikan harga yang terus menerus dan saling pengaruh mempengaruhi. Indikator yang sering digunakan untuk mengukur tingkat inflasi adalah Indeks Harga Konsumen (IHK) [2]. Indeks harga konsumen adalah ukuran rata-rata perubahan harga dari suatu paket komoditas dalam suatu kurun waktu tertentu. Peramalan

Peramalan adalah kegiatan untuk memperkirakan apa yang akan terjadi pada masa yang akan datang [3]. Peramalan merupakan bagian vital bagi setiap organisasi bisnis dan untuk setiap pengambilan keputusan manajemen yang sangat signifikan. Peramalan runtun waktu adalah serangkaian pengamatan terhadap suatu variabel yang diambil dari waktu ke waktu dan dicatat secara berurutan menurut urutan waktu [4].

\section{SARIMA}

Seasonal Autoregressive Integrated Moving Average atau yang lebih dikenal SARIMA adalah metode peramalan time series untuk model data fluktuatif dengan pola data musiman.

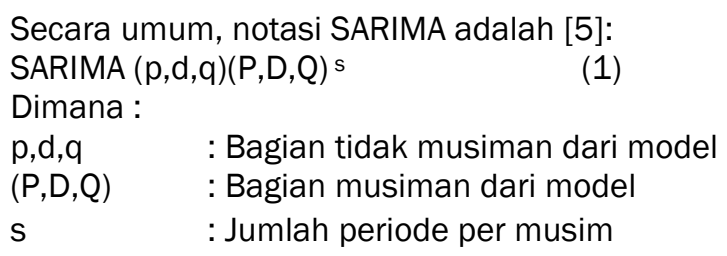

Rumus umum dari SARIMA $(p, d, q)(P, D, Q) s$ adalah sebagai berikut:

$$
\Phi_{\mathrm{p}} \mathrm{B}^{\mathrm{S}} \Phi_{\mathrm{p}}(\mathrm{B})(1-B)^{\mathrm{d}}\left(1-\mathrm{B}^{\mathrm{S}}\right)^{\mathrm{D}} \mathrm{Z}_{\mathrm{t}}=\theta_{\mathrm{q}}(B) \theta_{\mathrm{q}}\left(B^{\mathrm{S}}\right) \mathrm{a}_{\mathrm{t}}
$$

Dimana :

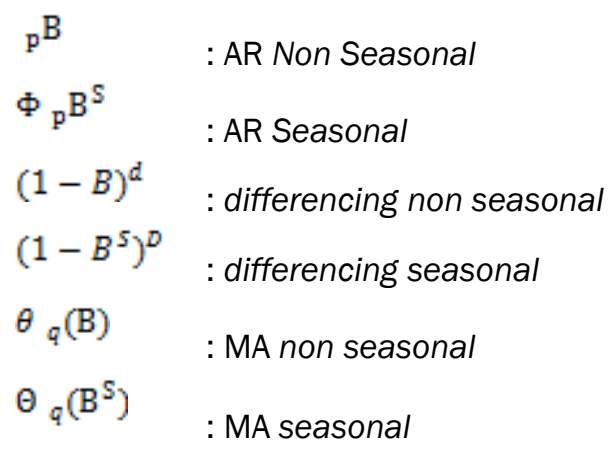

Dalam menetapkan nilai $\mathrm{p}$ dan $\mathrm{q}$ dapat dibantu dengan mengamati pola Autocorrelation Function (ACF) dan Partial Autocorrelation Function (PACF) dengan acuan pada tabel berikut [6]: 
Tabel 1. Pola Acf dan Pacf Untuk Identifikasi Parameter Tentatif

\begin{tabular}{|l|l|l|}
\hline Model & Pola ACF & Pola PACF \\
\hline ARMA (p,q) & $\begin{array}{l}\text { Menurun secara cepat } \\
\text { (dies down) }\end{array}$ & $\begin{array}{l}\text { Menurun secara cepat } \\
\text { (dies down) }\end{array}$ \\
\hline AR (p) atau & $\begin{array}{l}\text { Muncul spike yang } \\
\text { signifikan hingga lag } \\
\text { ke-q dan cut off } \\
\text { setelah lag ke-q }\end{array}$ & $\begin{array}{l}\text { Muncul spike yang } \\
\text { signifikan lag ke-p dan } \\
\text { cut off setelah lag ke- } \\
p\end{array}$ \\
\hline AR (p) & $\begin{array}{l}\text { Menurun secara cepat } \\
\text { (dies down) }\end{array}$ & $\begin{array}{l}\text { Muncul spike yang } \\
\text { signifikan hing- } \\
\text { ga lag ke-p dan cut off } \\
\text { setelah lag ke-p }\end{array}$ \\
\hline MA (q) & $\begin{array}{l}\text { Muncul spike yang } \\
\text { signifikan hing- } \\
\text { ga lag ke-q dan cut off } \\
\text { setelah lag ke-q }\end{array}$ & $\begin{array}{l}\text { Menurun secara cepat } \\
\text { (dies down) }\end{array}$ \\
\hline Muncul spike yang \\
MA (p) atau & $\begin{array}{l}\text { signifikan hingga lag } \\
\text { ke-q dan cut off } \\
\text { setelah lag ke-q }\end{array}$ & $\begin{array}{l}\text { Muncul spike yang } \\
\text { signifikan ingga lag ke } \\
\text {-p dan cut off } \\
\text { setelah lag ke-p }\end{array}$ \\
\hline
\end{tabular}

Tahapan pemeriksaan residual terbagi menjadi pemeriksaan L-jung Box (white noise), dan kenormalan residual. Pengujian untuk memenuhi asumsi white noise dilakukan pengujian L-jung Box dengan hipotesa :

$$
\mathrm{H}-0_{0}: \rho_{1}=\rho_{2}=\rho_{\mathrm{mm}}=\rho_{k}=0
$$

$\mathrm{H}_{1}$ : minimal ada satu nilai $\rho_{k} \neq 0$, dimana $\mathrm{k}=$ $1,2, \ldots, \mathrm{K}$

dengan statistik uji :

$$
Q=n(n+2) \Sigma_{k=1}^{K}(n-k)^{-1} \hat{\rho}_{k}
$$

Dimana $\mathrm{n}$ adalah banyak pengamatan dan $\hat{\rho}_{k}$ adalah sampel ACF residual pada lag ke-k, dan $\mathrm{K}$ adalah lag maksimum. Daerah kritis $=\mathrm{Q}>$ $x_{\left(a_{B} K-m\right)}^{2}$ atau $P$-value $<\alpha=5 \%$.

Pengujian kenormalan distribusi dapat dilakukan uji Kolmogorov-Smirnov dengan hipotesa:

$\mathrm{H}_{0}$ : residual berdistribusi normal

$\mathrm{H}_{1}$ : residual tidak berdistribusi normal

Dengan statistik uji :

$$
D={ }_{x}^{\sup }\left[\left|F_{n}(x)-F_{0}(x)\right|\right]
$$

Dimana $D$ adalah nilai deviasi absolut maksimum antara $F(x) n$ dan ( ) O F x , Sup masing-masing merupakan fungsi Kolmogorov peluang kumulatif yang dihitung dari data sampel, fungsi peluang kumulatif distribusi normal, dan nilai supremum untuk semua $\alpha_{-t}$. Daerah Kritis: Tolak HO jika
$D \geq D_{\left(\mathbb{1}-a_{0}\right)} \quad$ atau $P$-value $<\alpha$, dengan $\alpha=5 \%$. Model terbaik ditentukan berdasarkan nilai galat, semakin kecil nilai galat yang dihasilkan maka semakin baik model tersebut sekaligus menentukan model tersebut layak untuk digunakan pada peramalan. Berikut adalah proses peramalan menggunakan metode SARIMA.

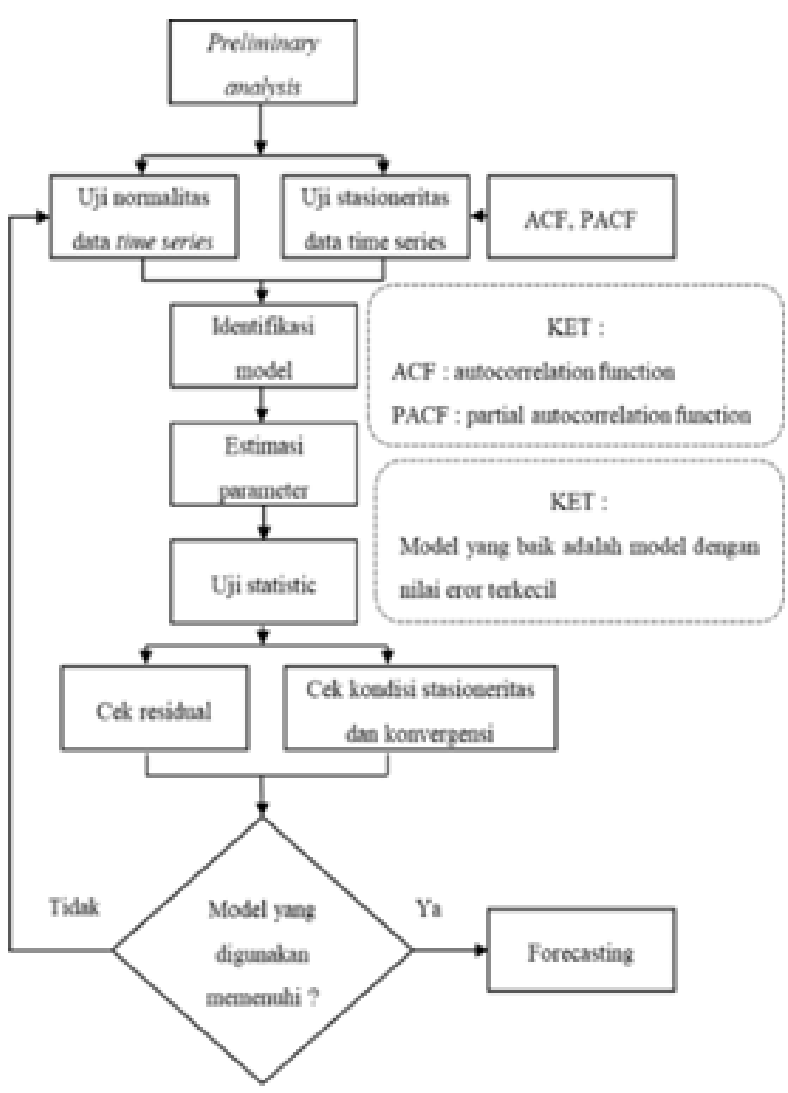

Gambar 1. Tahapan Metode SARIMA

Pada gambar 1 ditunjukkan proses peramalan dengan menggunakan metode SARIMA. Pada tahap awal dilakukan analisa awal pola data, setelah itu dilakukan pengujian normalitas dan stasioneritas data historis. Pada tahap ini hasil pengujian ditunjukkan dengan ACF dan PACF. Setelah itu dilakukan uji statistik dengan parameter estimasi. Pengujian statistik tersebut menghasilkan independensi residual. Dari residual ini akan diperiksa independensi dan normalitasnya, sehingga akan diketahui model SARIMA yang digunakan baik atau tidak. Model SARIMA terbaik adalah model dengan nilai 
error terkcecil. Nilai error dalam penelitian ini didapatkan dengan menghitung nilai MAD, MSE dan MAPE.

\section{Single Exponential Smoothing}

Metode ini juga sering disebut perataan eksponensial tunggal yang biasa dipakai trader untuk peramalan jangka pendek. Model mengansumsikan jika data berfluktuasi di sekitar nilai mean yang tetap, dan juga tanpa trend atau pola pertumbuhan konsisten [7]. Tidak seperti Moving Average, Exponential Smoothing akan menawarkan penekanan yang lebih besar pada runtun waktu melalui penggunaan sebuah konstanta smoothing. Rumus dasarnya adalah:

$$
\mathrm{S}_{\mathrm{t}+1}=\left(a * X_{\mathrm{t}}\right)+(1-\alpha) \mathrm{S}_{\mathrm{t}-1}
$$

$$
\begin{array}{ll} 
& \text { dimana: } \\
\text { a: } & \text { Konstanta pemulusan } \\
\text { t: } & \text { Periode waktu }
\end{array}
$$

Ada formula alternatif. Sebagai contoh, Roberts (1959) menggantikan $S_{t-1}$ dengan pengamatan saat ini. Rumus lain menggunakan ramalan untuk periode sebelumnya dan periode berjalan:

$$
F t=F_{t-1}+a\left(A_{t-1}-F_{t-1}\right)
$$

dimana:

Ft-1 : Perkiraan untuk periode sebelumnya,

At-1 : Permintaan nilai aktual untuk periode tersebut,

a : Berat (harus antara 0 dan 1). Semakin dekat ke nol, semakin kecil bobotnya.

Berikut adalah tahapan penggunaan metode Single Exponential Smoothing.

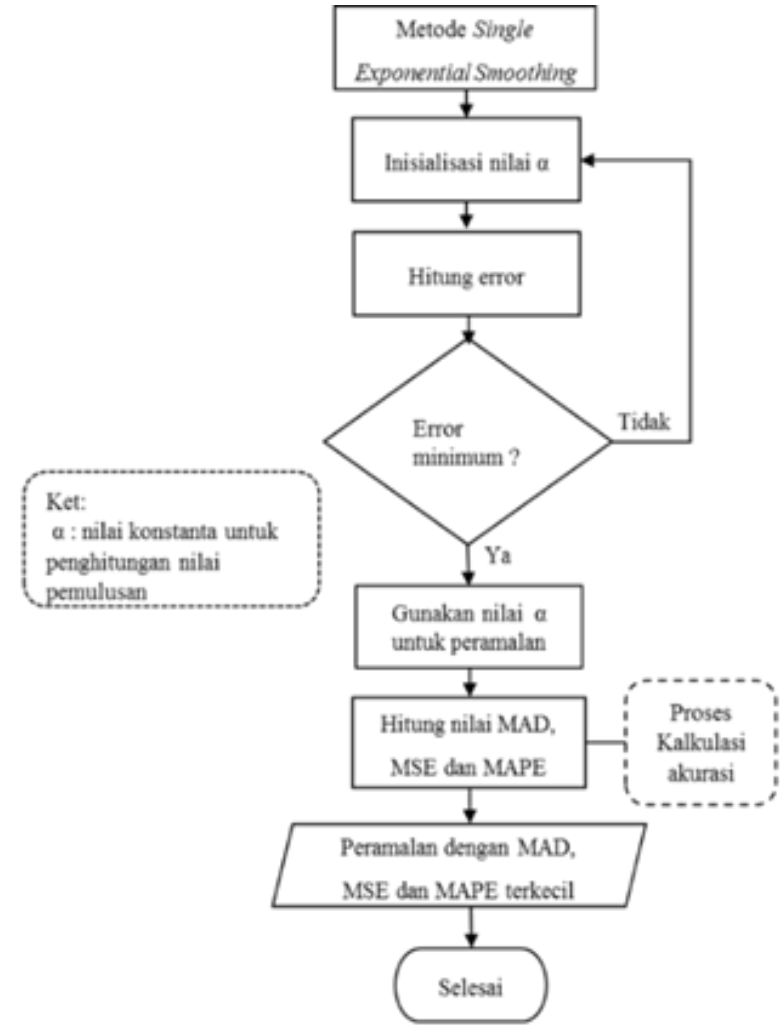

Gambar 2. Tahapan Metode Single Exponential Smoothing

Gambar 2 adalah gambaran dari tahapan yang dilakukan dalam penggunaan metode Single Exponential Smoothing. Langkah-langkah peramalan dengan metode SES adalah menganalisis data, apakah stasioner dengan melihat pola yang terbentuk, kemudian data diramalkan menggunakan SES, kemudian membandingkan nilai error terkecil.

\section{Evaluasi Hasil Peramalan}

Evaluasi hasil peramalan digunakan untuk mengetahui keakuratan hasil peramalan yang telah dil- 
akukan terhadap data yang sebenarnya. Terdapat banyak metode untuk melakukan perhitungan kesalahan peramalan. Beberapa metode yang digunakan adalah:

Mean Absolute Deviation adalah ukuran kesalahan peramalan keseluruhan untuk sebuah model. Nilai MAD dihitung dengan mengambil jumlah nilai absolut dari kesalahan peramalan dibagi dengan jumlah periode data $(n)[8]$.

$$
\begin{aligned}
& \text { MAD }=\frac{2 \mid \text { data aktual - peramalon } \mid}{n} \\
& \text { dimana: } \\
& \mathrm{n}=\text { jumlah periode data }
\end{aligned}
$$

Mean Squared Error merupakan rata-rata selisih kuadrat antara nilai yang diramalkan dan yang diamati. Kekurangan penggunaan MSE adalah bahwa metode evaluasi ini cenderung menonjolkan nilai deviasi yang besar karena adanya pengkuadratan.

$$
\text { MSE }=\frac{\left.\sum \text { (kesalahan peramalan }\right)^{2}}{n}
$$

dimana:

$\mathrm{n}=$ jumlah periode data

Mean Absolute Percentage Error adalah nilai ratarata dari selisih absolut antara nilai hasil peramalan dan nilai aktual, nilai ditunjukkan dalam persentase.

$$
\text { MAPE }=\sum_{t=1}^{T} \frac{\| \text { peramalan - actuaI }}{\text { aktual }} * 100
$$

\section{HASIL DAN PEMBAHASAN}

\section{Peramalan Menggunakan Metode SARIMA}

Data yang digunakan dalam peramalan ini adalah data inflasi Kota Bandung berdasarkan IHK tahun 2011 - 2017. Data diambil dari Badan Pusat Statistik (BPS) Kota Bandung.
Tabel 2. Data Inflasi Januari 2011 - Desember 2017

\begin{tabular}{|l|r|r|r|}
\hline Inflasi & \multicolumn{1}{|l|}{ 2016 } & \multicolumn{1}{l|}{2017} & 2018 \\
\hline Januari & 0,53 & 0,49 & 0.83 \\
\hline Februari & $-0,15$ & 0,38 & 0.22 \\
\hline Maret & 0,21 & $-0,02$ & 0.21 \\
\hline April & $-0,17$ & 0,11 & 0.27 \\
\hline Mei & 0,24 & 0,47 & 0.22 \\
\hline Juni & 0,64 & 0,99 & 0.48 \\
\hline Juli & 0,71 & $-0,27$ & 0.17 \\
\hline Agustus & 0,49 & 0,06 & -0.02 \\
\hline September & 0,14 & 0,11 & -0.24 \\
\hline Oktober & 0,14 & $-0,03$ & 0.50 \\
\hline November & 0,52 & 0,39 & 0.36 \\
\hline Desember & 0,64 & 0,73 & 0.71 \\
\hline
\end{tabular}

Tabel 2 adalah data runtun waktu nilai inflasi Kota Bandung sebagai data awal untuk melakukan peramalan dalam penelitian ini. Langkah pertama yang dilakukan pada metode SARIMA adalah proses identifikasi model.

a. Identifikasi Model:

Proses identifikasi model data dilakukan dengan melihat plot data asli, sekaligus dilihat apakah data stasioner atau tidak dengan melihat plot ACF dan PACF. Berdasarkan Bank Indonesia inflasi mengalami kenaikan ketika satu bulan sebelum hari raya idul fitri dan kemudian turun atau stabil ketika satu bulan setelah hari raya idul fitri. Hal ini dikarenakan adanya peningkataan volatille foods, akibat peningkatan konsumsi dan karena adanya ekspektasi masyarakat tentang kenaikan harga menjelang Hari Raya Idul Fitri.

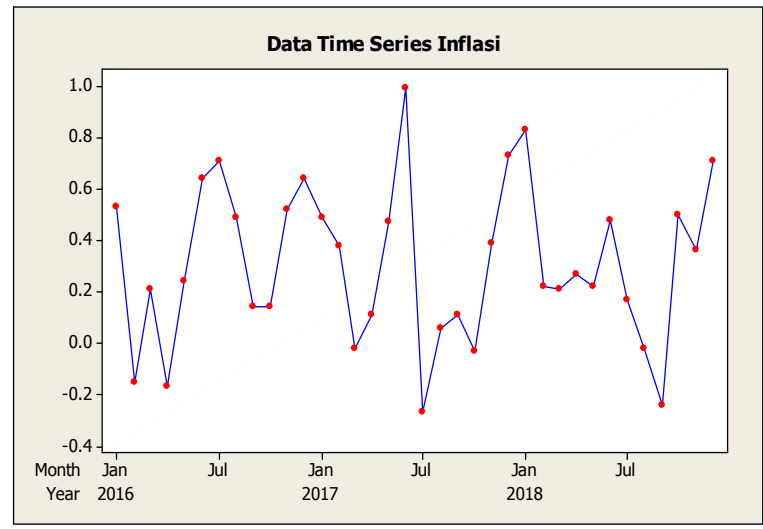

Gambar 3. Data Inflasi 
Gambar 3 memperlihatkan bahwa data dipengaruhi pola musiman karena terjadi pengulangan pola pada periode tertentu (tahunan).

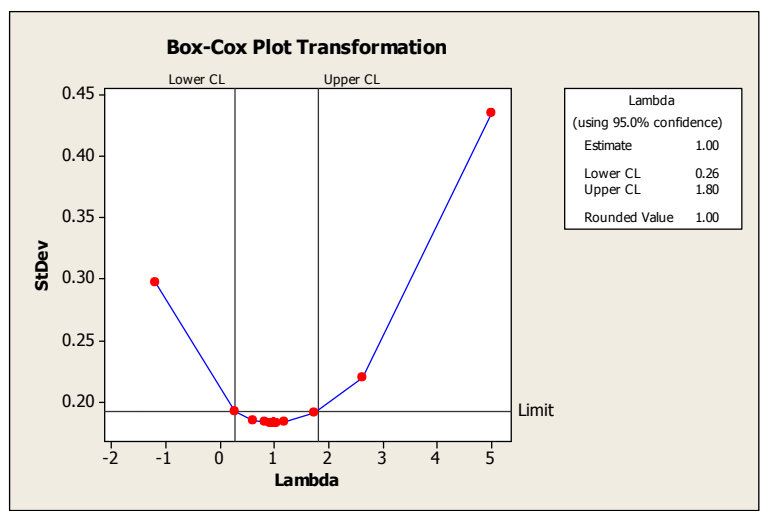

Gambar 4. Proses Box-Cox Transformation

Gambar 4 memperlihatkan hasil proses transformasi data dengan Box-Cox Transformation. Data berstatus sudah stasioner terhadap ragam karena nilai Rounded Value pada Box-Cox plot sudah bernilai 1,00 .

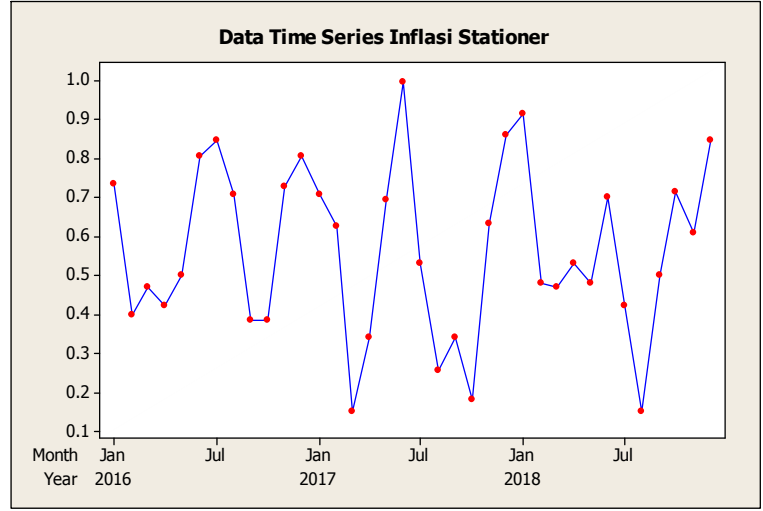

Gambar 5. Data Time Series Inflasi Stationer

Gambar 5 memperlihatkan hasil proses transformasi data dengan Box-Cox Transformation data berstatus sudah stasioner. Selanjutnya data akan dilihat stationeritasnya dengan melihat pola ACF dan PACF.

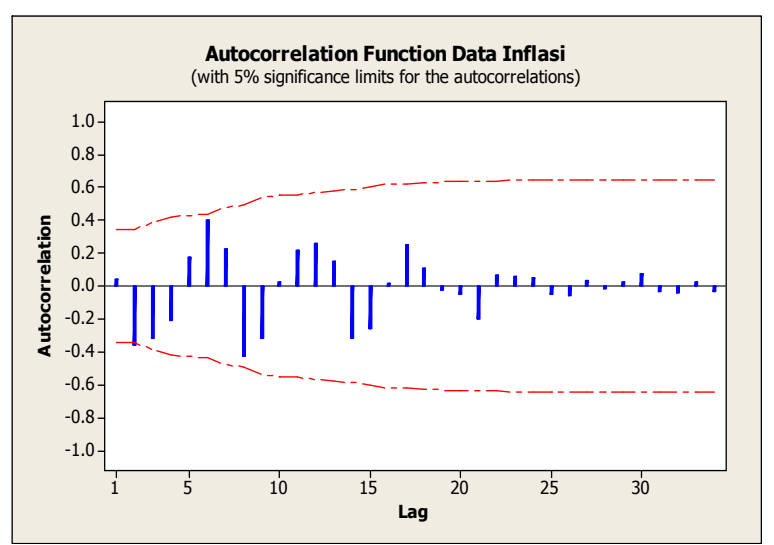

Gambar 6. Plot ACF

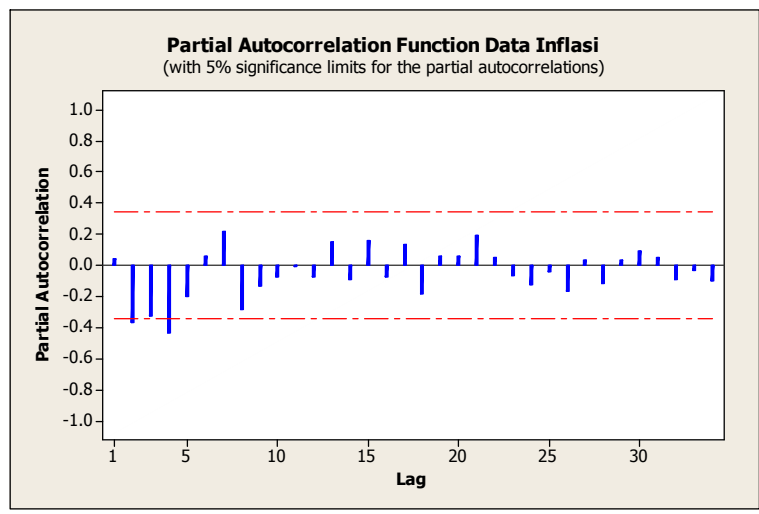

Gambar 7. Plot PACF

Pada gambar 6 dan 7 memperlihatkan plot ACF dan PACF, dimana plot ACF dan PACF dapat digunakan untuk mengidentifikasi kandidat model yang sesuai untuk data inflasi Kota Bandung. Jika ACF dan PACF menunjukkan dies down yang artinya baik pola ACF ataupun pola PACF mengalami penurunan drastis pada setiap lag maka dapat dikatakan model SARIMA berupa gabungan AR dan MA.

b. Pendugaan Parameter:

Kandidat model yang dihasilkan dari pendugaan sebelumnya dengan melihat pola ACF dan PACF yang menyatakan bahwa model adalah gabungan dari AR dan MA. Berikut adalah model yang dihasilkan oleh metode SARIMA terhadap pergerakan inflasi di Kota Bandung. 
Tabel 3. Kandidat Model Sarima Data Inflasi

\begin{tabular}{|l|l|l|l|l|}
\hline $\begin{array}{l}\text { Model SARIMA } \\
(p, d, q)(P, D, Q)\end{array}$ & MAD & MSE & MAPE & Keterangan \\
\hline $\begin{array}{l}\text { SARIMA (1,1,1) } \\
(1,1,0)^{11}\end{array}$ & 0,364 & 0,214 & $1,04 \%$ & Tidak Signifikan \\
\hline $\begin{array}{l}\text { SARIMA (2,1,1) } \\
(1,1,1)^{11}\end{array}$ & 0.117 & 0.023 & $0.72 \%$ & Signifikan \\
\hline $\begin{array}{l}\text { SARIMA (1,1,0) } \\
(1,1,0)^{11}\end{array}$ & 0,308 & 0,152 & $0,81 \%$ & Tidak Signifikan \\
\hline $\begin{array}{l}\text { SARIMA (1,1,1) } \\
(1,1,1)^{11}\end{array}$ & 0,142 & 0,025 & $0,95 \%$ & Signifikan \\
\hline $\begin{array}{l}\text { SARIMA (1,1,1) } \\
(1,0,1)^{11}\end{array}$ & 0,141 & 0,025 & $0,93 \%$ & Signifikan \\
\hline
\end{tabular}

Dari tabel 3 di atas dapat disimpulkan bahwa model SARIMA $(p, d, q)(P, D, Q)^{12}$ yang memenuhi syarat signifikansi adalah model SARIMA $(2,1,1)(0,1,1)^{11}$ dan SARIMA $(1,1,1)(1,1,1)^{11}$ karena semua parameternya signifikan ( nilai $P<0,05$ ). Sedangkan model yang terbaik untuk data inflasi adalah SARIMA $(2,1,1)(1,1,1)^{11}$ karena memiliki nilai galat terkecil yaitu 0.117 untuk MAD, 0.023 untuk MSE dan $0.72 \%$ untuk MAPE. Hal ini menunjukkan bahwa model ini baik digunakan untuk peramalan.

\section{c. Pemeriksaan Residual:}

Setelah model SARIMA (p,d,q)(P,D,Q) ${ }^{11}$ didapatkan kemudian dilakukan pemeriksaan residual yaitu uji white noise dan kenormalan residual pada model yang digunakan. Uji white noise pada metode SARIMA dilihat dari nilai L-jung Box (nilai Pr / P-value pada software minitab). Nilai P-value pada setiap lag lebih besar daripada 0.05 sehingga dapat disimpulkan bahwa residual yang dihasilkan model SARIMA telah white noise.

\begin{tabular}{|l|l|l|l|l|}
\hline $\begin{array}{l}\text { Modified } \\
\text { Square statistic }\end{array}$ \\
\hline Lag & 12 & 24 & 36 & 48 \\
\hline $\begin{array}{l}\text { Chi- } \\
\text { Square }\end{array}$ & 18,7 & 29,7 & 45,4 & 52,3 \\
\hline DF & 9 & 21 & 33 & 45 \\
\hline P-Value & $\begin{array}{l}0,02 \\
8\end{array}$ & $\begin{array}{l}0,09 \\
9\end{array}$ & $\begin{array}{l}0,07 \\
3\end{array}$ & $\begin{array}{l}0,21 \\
1\end{array}$ \\
\hline
\end{tabular}

Untuk melihat apakah residual berdistribusi normal, dapat dilakukan dengan pengujian KolmogorovSmirnov dengan membandingkan distribusi data yang akan diuji normalitasnya dengan distribusi normal baku.

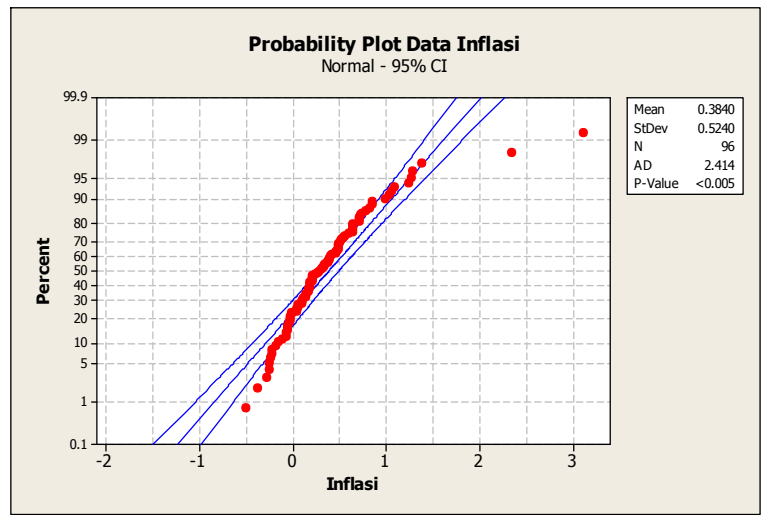

Gambar 8. Plot Normal Residual

Pada gambar 8 dapat dilihat data terletak di sekitar garis lurus meskipun beberapa titik menyimpang cukup jauh dari garis lurus. Dengan demikian dapat diartikan bahwa residual sudah identik dan berdistribusi normal.

d. Hasil Peramalan Metode SARIMA:

Berikut adalah hasil peramalan yang dihasilkan oleh metode SARIMA terhadap pergerakan inflasi pada tahun 2016 - 2018 di Kota Bandung.

Tabel 4. Hasil Peramalan Metode Sarima

\begin{tabular}{|c|c|c|c|c|c|}
\hline $\begin{array}{l}\text { Peri- } \\
\text { ode } \\
2019\end{array}$ & $\begin{array}{c}\text { Nilai } \\
\text { Aktual } \\
\text { (a) }\end{array}$ & $\begin{array}{c}\text { Hasil } \\
\text { Peramalan } \\
\text { (t) }\end{array}$ & $\begin{array}{c}\text { Error } \\
\text { Absolut } \\
\left|\mathrm{A}_{\mathrm{t}}-\mathrm{F}_{\mathrm{t}}\right|\end{array}$ & $\begin{array}{c}\text { Square } \\
\text { Of } \boldsymbol{E r} \text { - } \\
\boldsymbol{r o r} \\
\mid(\mathrm{At}- \\
\mathrm{Ft})^{2} \mid\end{array}$ & $\begin{array}{c}\text { Absolute } \\
\text { Values } \\
\text { Of Errors } \\
\text { | (At -Ft)/ } \\
\text { At| }\end{array}$ \\
\hline Jan & 0.09 & 0.15 & -0.06 & 0.004 & 0.69 \\
\hline Feb & -0.08 & -0.03 & -0.05 & 0.002 & 0.63 \\
\hline Mar & 0.03 & 0.07 & -0.04 & 0.001 & 1.42 \\
\hline Apr & 0.43 & 0.12 & 0.30 & 0.094 & 0.71 \\
\hline Mei & 0.84 & 0.67 & -0.16 & 0.028 & 0.20 \\
\hline Jun & 0.11 & 0.18 & -0.06 & 0.004 & 0.62 \\
\hline \multicolumn{3}{|c|}{ Nilai Error } & $\begin{array}{c}\text { MAD } \\
0,117\end{array}$ & $\begin{array}{c}\text { MSE } \\
0,023\end{array}$ & $\begin{array}{l}\text { MAPE } \\
0,72 \%\end{array}$ \\
\hline
\end{tabular}

Tabel 4 memperlihatkan hasil peramalan dengan model SARIMA $(2,1,1)(1,1,1)^{11}$ untuk periode Januari 2019 - Juni 2019. 


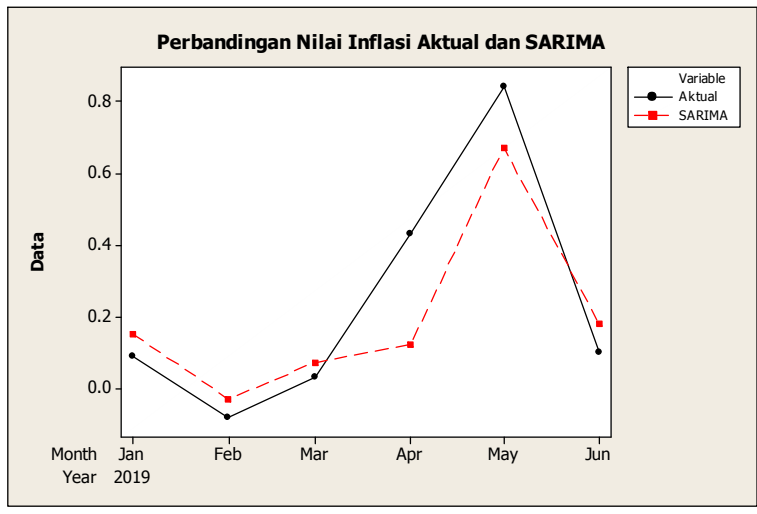

Gambar 9. Grafik Perbandingan Nilai Inflasi Aktual dan SARIMA

Gambar 9 adalah gambar grafik perbandingan nilai aktual dan model SARIMA $(2,1,1)(1,1,1)^{11}$ dengan nilai error terkecil yaitu MAD 0,117, MSE 0,023 dan MAPE 0,72\% untuk peramalan periode Januari 2019 - Juni 2019.

\section{Peramalan Menggunakan Metode Single Expo- nential Smoothing}

Dari data inflasi bulanan periode Januari 2016 Desember 2018, akan diramalkan model yang cocok untuk metode SES dengan melihat hasil peramalan yang dibandingkan dengan nilai aktual.

\section{a. Penentuan Model Single Exponential Smoothing:}

Langkah-langkah peramalan dengan metode SES adalah menganalisis data, kemudian data diramalkan dengan menentukan nilai alpha yang cocok untuk dijadikan model peramalan. Kemudian membandingkan manakah nilai error terkecil, penentuan metode yang tepat dilakukan secara trial and error yakni nilai parameter diubah-ubah hingga didapat eror terkecil.

Tabel 5. Penentuan Nilai Aplha

\begin{tabular}{|l|l|l|l|}
\hline Alpha (a) & MAD & MSE & MAPE \\
\hline 0,1 & 0.308 & 0.217 & $5.94 \%$ \\
\hline 0,2 & 0.324 & 0.128 & $2.86 \%$ \\
\hline 0,3 & 0.346 & 0.142 & $2.90 \%$ \\
\hline 0,4 & 0.367 & 0.157 & $2.94 \%$ \\
\hline 0,5 & 0.383 & 0.172 & $2.92 \%$ \\
\hline 0,6 & 0.373 & 0.187 & $2.84 \%$ \\
\hline 0,7 & 0.401 & 0.199 & $2.85 \%$ \\
\hline 0,8 & 0.412 & 0.209 & $3.16 \%$ \\
\hline 0,9 & 0.417 & 0.218 & $3.37 \%$ \\
\hline
\end{tabular}

Pada Tabel 5 dapat dilihat model Single Exponential Smoothing dengan nilai error MAD, MSE dan MAPE terkecil terdapat pada model alpha 0,2 dengan nilai MAD 0.324, MSE 0.128 dan MAPE 2.86\%.

b. Hasil Peramalan Metode Single Exponential Smoothing:

Metode yang sesuai untuk peramalan pada pergerakan inflasi di Kota Bandung adalah dengan metode Single Exponential Smoothing dengan alpha 0.6 karena berdasarkan perhitungan error memiliki error forecast yang lebih baik dibanding dengan metode peramalan yang lain.

Forecast Januari $\begin{aligned} 2019 & =0.25+0.2 *(0.71-0.25) \\ & =0.34\end{aligned}$

Forecast Februari $2019=0.34+0.2 *(0.09-0.34)$$$
=0.29
$$

Forecast Maret $2019=0.34+0.2 *((-0.08)-0.34)$

$=0.22$

Forecast April $2019=0.22+0.2 *(0.03-0.22)$

$=0.18$

Forecast Mei $2019=0.18+0.2 *(0.43-0.18)$

$=0.23$

Forecast Juni $2019=0.23+0.2 *(0.87-0.23)$

$=0.36$

Berikut adalah hasil peramalan yang dihasilkan oleh metode Single Exponential Smoothing terhadap pergerakan inflasi pada tahun 2016 - 2018 di Kota Bandung.

Tabel 6. Hasil Peramalan Metode SES

\begin{tabular}{|l|c|c|c|c|c|}
\hline $\begin{array}{l}\text { Peri- } \\
\text { ode } \\
2019\end{array}$ & $\begin{array}{c}\text { Nilai } \\
\text { Aktual } \\
(\mathrm{a})\end{array}$ & $\begin{array}{c}\text { Hasil } \\
\text { Peramalan } \\
(\mathrm{t})\end{array}$ & $\begin{array}{c}\text { Error } \\
\text { Absolut } \\
\left|\mathrm{A}_{\mathrm{t}}-\mathrm{F}_{\mathrm{t}}\right|\end{array}$ & $\begin{array}{c}\text { Square } \\
\text { Of } \\
\text { Error } \\
\mid(\text { At - } \\
\mathrm{Ft})_{2} \mid\end{array}$ & $\begin{array}{c}\text { Absolute } \\
\text { Values } \\
\text { Of Errors } \\
\mid(\text { At }-\mathrm{Ft}) / \\
\mathrm{At} \mid\end{array}$ \\
\hline Jan & 0.09 & 0.34 & -0.25 & 0.25 & 2.78 \\
\hline Feb & -0.08 & 0.29 & -0.37 & 0.37 & 4.63 \\
\hline Mar & 0.03 & 0.22 & -0.19 & 0.19 & 6.20 \\
\hline Apr & 0.43 & 0.18 & 0.25 & 0.25 & 0.58 \\
\hline Mei & 0.84 & 0.23 & 0.64 & 0.64 & 0.74 \\
\hline Jun & 0.11 & 0.36 & -0.25 & 0.25 & 2.25 \\
\hline Nilai Error & & $\begin{array}{l}\text { MAD } \\
\text { MSE }\end{array}$ & $\begin{array}{l}\text { MSE } \\
\text { MAPE }\end{array}$ \\
\hline
\end{tabular}

Tabel 6 memperlihatkan hasil peramalan dengan model SES dengan nilai alpha 0.2 untuk periode Januari 2019 - Juni 2019 dengan nilai MAD 0.324, MSE 0.128 dan MAPE $2.86 \%$. 


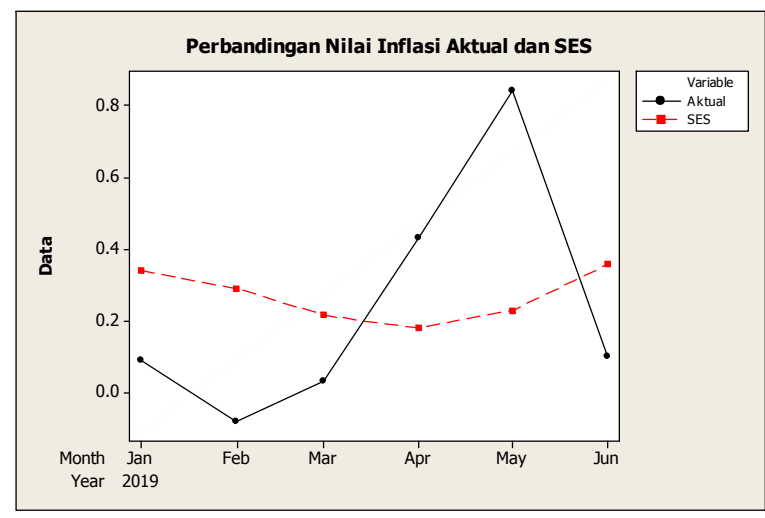

Gambar 10. Grafik Perbandingan Nilai Inflasi Aktual dan SES

Gambar 10 adalah gambar grafik perbandingan nilai aktual dan model SES dengan nilai alpha 0.2 untuk periode Januari 2019 - Juni 2019 dengan nilai error terkecil yaitu MAD 0.324, MSE 0.128 dan MAPE $2.86 \%$.

\section{c. Perbandingan Nilai Error:}

Berikut adalah perbandingan nilai error peramalan yang dihasilkan oleh metode SARIMA dan metode Single Exponential Smoothing terhadap pergerakan inflasi pada tahun 2016 - 2018 di Kota Bandung.

Tabel 7. Perbandingan Nilai Error

\begin{tabular}{|l|c|c|c|}
\hline $\begin{array}{c}\text { Peri- } \\
\text { ode } \\
2019\end{array}$ & Aktual & SARIMA & $\begin{array}{c}\text { Single } \\
\text { Exponential } \\
\text { Smoothing }\end{array}$ \\
\hline Januari & 0.09 & 0.15 & 0.34 \\
\hline $\begin{array}{l}\text { Febru- } \\
\text { ari }\end{array}$ & -0.08 & -0.03 & 0.29 \\
\hline Maret & 0.03 & 0.07 & 0.22 \\
\hline April & 0.43 & 0.12 & 0.18 \\
\hline Mei & 0.84 & 0.67 & 0.23 \\
\hline Juni & 0.11 & 0.18 & 0.36 \\
\hline \multirow{5}{*}{ Nilai Error } & & MAD & MAD \\
& & 0.117 & 0.324 \\
\cline { 3 - 4 } & & MSE & MSE \\
& & 0.023 & 0.128 \\
\cline { 2 - 4 } & MAPE & MAPE \\
& $0.72 \%$ & $2.86 \%$ \\
\hline
\end{tabular}

Dalam tabel 7 diperlihatkan bahwa hasil metode SARIMA lebih baik dibandingkan dengan menggunakan metode SES. Dilihat dari nilai MAD, MSE dan MAPE yang lebih kecil jika dibandingkan dengan nilai MAD, MSE dan MAPE dari semua model yang dihasilkan, dengan nilai MAD 0.117, MSE 0.023 dan $0.72 \%$ untuk MAPE. Berikut adalah grafik perbandingan nilai aktual, metode SARIMA dan metode Single Exponential Smoothing.

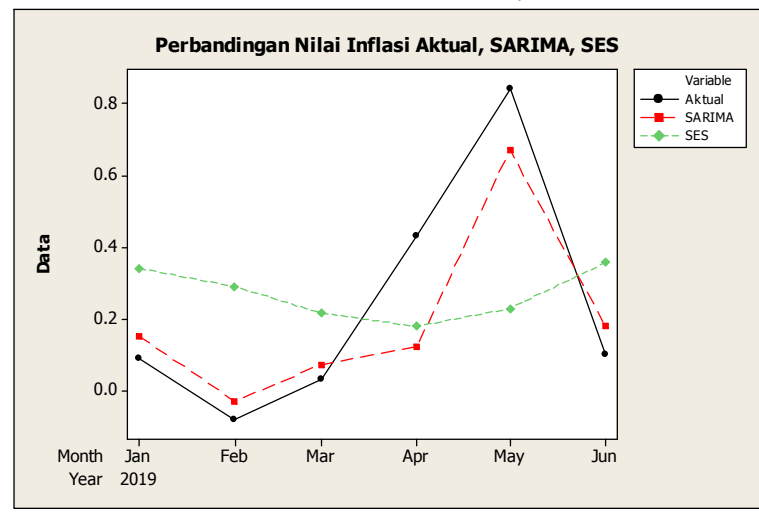

Gambar 11. Grafik Perbandingan Nilai Inflasi Aktual, SARIMA dan Single Exponential Smoothing

Gambar 11 adalah gambar grafik perbandingan nilai inflasi aktual, nilai inflasi hasil peramalan SARIMA dan nilai inflasi hasil peramalan Single Exponential. Dapat dilihat dalam grafik metode SARIMA memiliki pola yang mirip dengan data aktual. Artinya hasil peramalan inflasi menggunakan SARIMA memiliki hasil yang lebih baik dibandingnya dengan Single Exponential Smoothing.

\section{KESIMPULAN}

Penggunaan metode SARIMA dengan model SARIMA $(2,1,1)(1,1,1)^{11}$ untuk peramalan nilai inflasi Kota Bandung menghasilkan nilai peramalan yang lebih akurat dibandingkan menggunakan metode SES ataupun semua model yang dihasilkan oleh kedua metode tersebut, dengan nilai error MAD 0.117, MSE 0.023 dan MAPE 0.72\%. Sehingga hasil implementasi peramalan nilai inflasi Kota Bandung untuk periode berikutnya dapat dijadikan acuan untuk pengambilan keputusan dalam menentukan kebijakan.

\section{UCAPAN TERIMAKASIH}

Saya ingin mengucapkan terima kasih yang tulus kepada Assoc. Prof. Dr. Ir. Eddy Soeryanto Soegoto, MT selaku Rektor Universitas Komputer Indonesia dan Dr. Yeffry Handoko Putra, ST., M.T selaku Ketua Prodi Magister Sistem Informasi. Terima kasih kepada Irfan Dwiguna Sumitra, M.Kom., Ph.D. selaku dosen pembimbing yang telah memberikan dukungan dan bimbingan penuh sehingga tulisan ini dapat direalisasikan. Serta tidak lupa ucapan terima kasih khusus saya berikan kepada Kementrian Riset, Teknologi dan Pendidikan Tinggi Republik Indonesia atas program Hibah Penelitian Tesis Magister dengan nomor kontrak: No. 2898 / L4 / PP / 2019. 


\section{DAFTAR PUSTAKA}

[1] Suseno, S. A. (2009). Inflasi. Jakarta: Pusat Pendidikan dan Studi Kebanksentralan (PPSK) BI.

[2] Swandayani, D. M., \& Kusumaningtias, R. (2012). Pengaruh Inflasi, Suku Bunga, Nilai Tukar Valas dan Jumlah Uang Beredar terhadap Profitabilitas pada Perbankan Syariah di Indonesia Periode 2005-2009. AKRUAL: Jurnal Akuntansi, 3(2), 147-166.

[3] A. Sofyan, (1984). Teknik dan metode peramalan, Jakarta Penerbit Fak.Ekonomi Universitas Indonesia.

[4] W. W. S. Wei, (2006). Time Series Analysis Univariate and Multivariate Methods SECOND EDITION.
[5] Fahrudin, R. (2018, August). Forecasting Tourist Visits Using Seasonal Autoregressive Integrated Moving Average Method. In IOP Conference Series: Materials Science and Engineering (407.1, p.012148). IOP Publishing.

[6] B. L Bowerman and R. T O Connell, (2018). Forecasting and time series: an applied approach / Bruce L. Bowerman, Richard T. O`Connell.

[7] Biri, R., Langi, Y. A., \& Paendong, M. S. (2013). Penggunaan Metode Smoothing Eksponensial dalam Meramal Pergerakan Inflasi Kota Palu. Jurnal IImiah Sains, 13(1), 68-73.

[8] S. G. Makridakis, S. C. Wheelwright, and R. J. Hyndman, "Forecasting:

[9] Methods and Applications," J. Forecast., p. 1, 1998. 